\title{
RANCANGAN FORMAT LAPORAN KEUANGAN USAHA MIKRO DAN FORM APLIKASI PEMBIAYAAN UNTUK ANALISA KEUANGAN NASABAH PEMBIAYAAN PADA BMT
}

\author{
Taufik Hidayat dan Sri Mulyati \\ Accounting and Tax Department di PMA Services dan \\ Program Studi Akuntansi Syariah STEI SEBI \\ Email:opick.center@gmail.com dan sri.mulyati@sebi.ac.id
}

\begin{abstract}
ABSTRAK
Pokok permasalahan yang dibahas adalah BMT dalam menilai aspek keuangan nasabah pembiayaan tidak secara komprehensif hanya menilai aspek arus kas saja. Oleh karena itu BMT dalam menganalisis aspek keuangan nasabah harus memiliki form aplikasi pembiayaan yang terhubung secara langsung ke laporan keuangan usaha mikro secara komprehensif. Disatu sisi dengan rancangan tersebut akan membantu usaha mikro dalam pembuatan laporan keuangan. Pendekatan penelitian yang digunakan adalah deskriptif kualitatif. Dengan melihat aspek kejadian permasalahan dilapangan yaitu di BMT dan Usaha Mikro yang menjadi nasabah BMT. Untuk melihat situasi sosial yang ada, lalu dibuatkan rancangan yang ideal. Hasil yang didapat dari penelitian ini adalah rancangan form aplikasi pembiayaan dan format laporan keuangan usaha mikro yang nantinya digunakan BMT dalam menilai aspek keuangan nasabah pembiayaan secara komprehensif dan membantu usaha mikro dalam aspek pembuatan laporan keuangan.
\end{abstract}

Kata Kunci: rancangan form aplikasi pembiayaan, format laporan keuangan usaha mikro

\section{PENDAHULUAN}

Peran UMKM (Usaha Mikro Kecil dan Menengah) selama ini diakui berbagai pihak cukup besar dalam perekonomian nasional. Beberapa peran strategis UMKM menurut Bank Indonesia antara lain: (a) jumlahnya yang besar dan terdapat dalam setiap sektor ekonomi, (b) menyerap banyak tenaga kerja dan setiap investasi menciptakan lebih banyak kesempatan kerja, (c) memiliki kemampuan untuk memanfaatkan bahan baku lokal dan menghasilkan barang dan jasa yang dibutuhkan masyarakat luas dengan harga terjangkau. Dalam posisi strategis tersebut, pada sisi lain UMKM masih menghadapi banyak masalah dan hambatan dalam melaksanakan dan mengembangkan aktivitas usahanya. Sebenarnya masalah dan kendala yang dihadapi masih bersifat klasik yang selama ini telah sering diungkapkan, antara lain: 1) manajemen, 2) permodalan, 3) Teknologi, 4) bahan baku, 5) informasi dan pemasaran, 6) infrastruktur, 7) birokrasi dan pungutan, serta 8) kemitraan. (Bidang Pengkajian Sumberdaya UKMK Asdep Urusan Penelitian UKM, 2011) 
Pernyataan di atas tercermin dalam data dibawah ini. pertama, UMKM terbukti lebih tahan dalam menghadapi krisis ekonomi luar negeri yang berimbas terhadap perekonomian Indonesia seperti krisis subprime mortgage yang terjadi pada tahun 2008. Jumlah UMKM yang bertahan dan berkembang sampai saat ini mengalami jumlah yang meningkat, tercermin dalam grafik dibawah ini

Grafik 1. Jumlah Pelaku UMKM Tahun 2006-2010 (dalam unit)

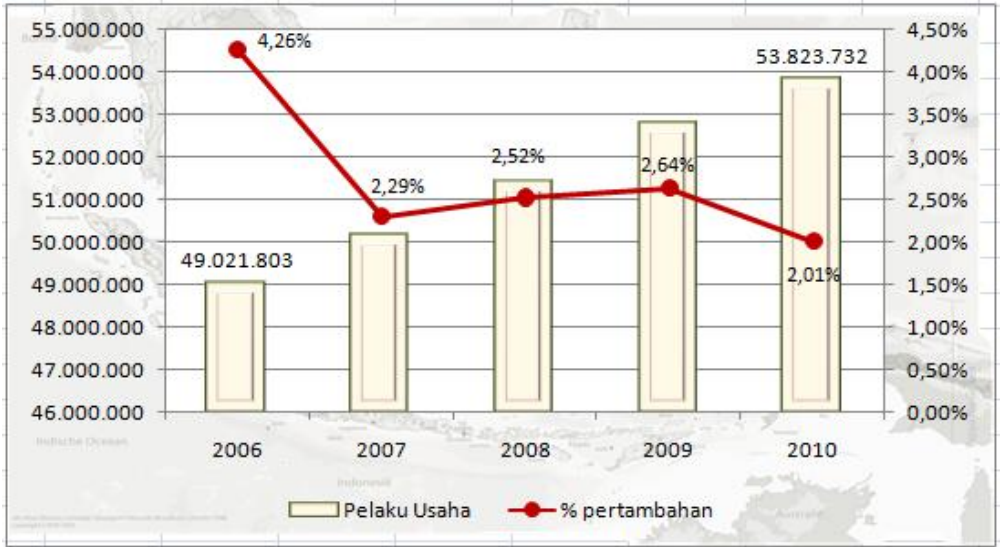

Sumber diolah: Perkembangan data usaha mikro, kecil menengah (umkm) Kementrian Koperasi dan UKM

Dari Grafik 1 dapat dilihat bahwa jumlah pelaku UMKM setiap tahun meningkat. Padahal, bulan September 2008 terjadi krisis subprime mortgage namun tingkat pertumbuhan pelaku UMKM ditahun 2009 justru tetap bertambah sebesar 2,64\% dari tahun 2008.

Kedua, UMKM dapat menjadi sarana pemerataan kesejahteraan rakyat, dengan jumlahnya yang besar dan sifatnya yang umumnya padat karya, dengan demikian UMKM mampu menyerap tenaga kerja yang cukup signifikan. Penyerapan tenaga kerja oleh UMKM dapat dilihat pada grafik berikut ini.

Grafik 2 Penyerapan Tenaga Kerja oleh UMKM (dalam juta orang)

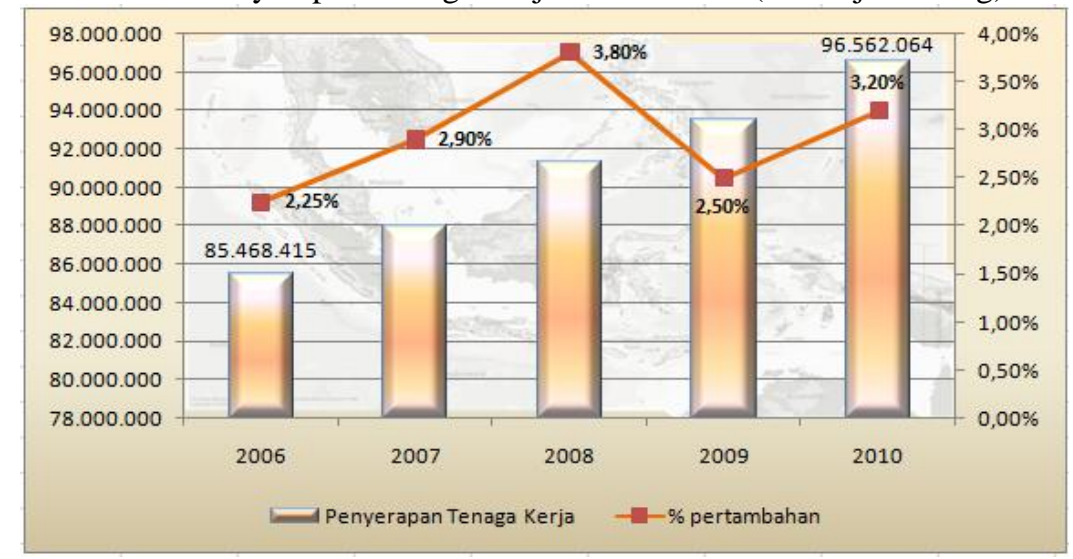

Sumber diolah: Perkembangan data usaha mikro, kecil menengah (umkm) Kementrian Koperasi dan UKM 
Dari Grafik 2 di atas dapat dilihat bahwa penyerapan tenaga kerja oleh UMKM terus bertambah setiap tahunnya. Hingga tahun 2010, UMKM mampu menyerap tenaga kerja sebanyak 96.562 .064 juta jiwa atau meningkat sebesar $3,3 \%$.

UMKM merupakan salah satu sektor yang dapat memberikan kontribusi besar bagi perekonomian nasional, namun sektor ini pada umumnya mengalami beberapa permasalahan. Berdasarkan hasil penelitian kerjasama Kementerian Koperasi dan UMKM dengan Badan Pusat Statistik (BPS) pada tahun 2003 mengemukakan bahwa UMKM yang mengalami kesulitan usaha adalah $74,47 \%$ dan sisanya 27,53\% tidak ada masalah (Nugroho, 2009). Dari 72,47\% tersebut, jenis-jenis permasalahan yang dialami dapat dilihat pada grafik 3 .

Grafik 3. Permasalahan UMKM pada Umumnya

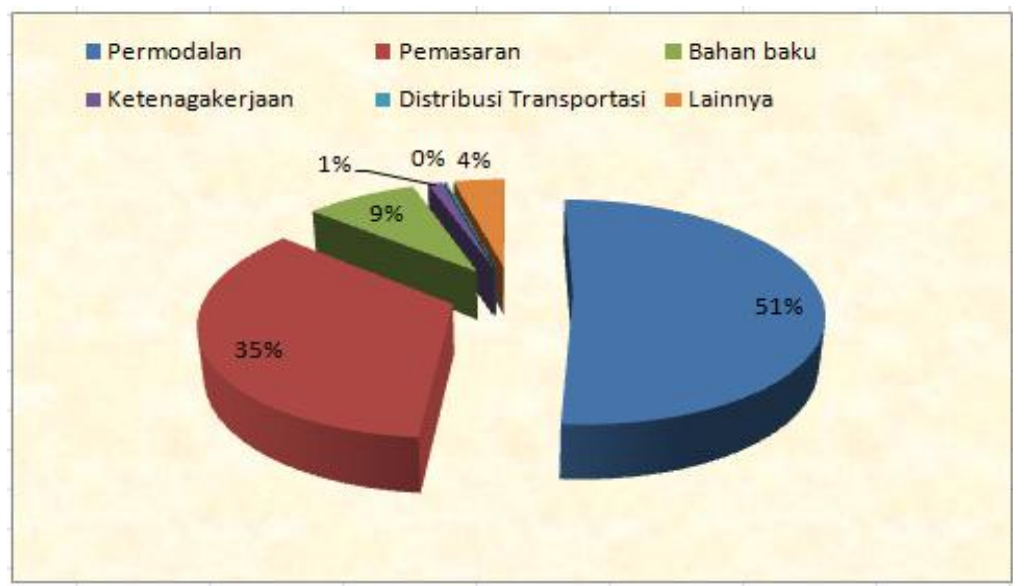

Sumber diolah: Penelitian Kementrian Koperasi dan UMKM dengan BPS Tahun 2003

Dari Grafik 1.3, dapat dilihat bahwa permodalan merupakan permasalahan terbesar yakni dengan porsi $51 \%$. Hal ini dikarenakan dari total permodalan yang dibutuhkan hanya 12,81\% yang dapat terpenuhi oleh UMKM (modal sendiri). (Budhiningsih, 2009)

Disamping adanya berbagai potensi, terdapat juga kendala yang dihadapi UMKM khususnya kendala masalah permodalan. Adanya anggapan bahwa UMKM bukanlah kelompok usaha yang layak untuk menjadi nasabah perbankan dan sebaliknya bank bukanlah lembaga yang potensial untuk menjadi sumber permodalan UMKM. (Bidang Pengkajian Sumberdaya UKMK Kementrian Negara Koperasi dan UKM, 2007)

Ketidaklayakan UMKM terkait dengan karakter dari UMKM yang pada umumnya merupakan perusahaan keluarga atau perusahaan tradisional. UMKM tidak memiliki sistem pembukuan yang standar dengan ketentuan perbankan. Demikian juga, UMKM tidak memiliki agunan yang cukup. Masalah ketiga yang menghambat hubungan UMKM dengan perbankan adalah jumlah kredit yang dibutuhkan UMKM biasanya kecil-kecil. hal tersebut menyebabkan tingginya biaya operasional bank. Demikian juga perbankan dianggap bukan sumber yang 
layak bagi UMKM untuk mendapatkan pinjaman modal (Deputi Bidang Pengkajian Sumberdaya UKMK Kementrian Negara Koperasi dan UKM, 2007).

Dilihat dari beberapa data diatas kebutuhan akan modal usaha bagi para pelaku UMKM sangat besar. Dalam penelitian terdahulu oleh Hafidz dan Sondakh dari hasil penelitiannya di 27 provinsi di Indonesia secara tegas menyatakan bahwa kelompok miskin memerlukan bantuan pinjaman modal. Bank komersial tidak dapat dijadikan sandaran oleh kelompok miskin karena kelompok ini tidak akan mampu memenuhi persyaratan yang diminta oleh pihak bank (the five $C$ of credit). Hal ini juga telah dikemukakan oleh Yunus (2002) bahwa bank komersil mengharuskan adanya jaminan dan berbagai persyaratan administratif lainnya. Persyaratan tersebut tidak mungkin dipenuhi oleh mereka (kaum miskin). Untuk membantu rakyat miskin seharusnya stakeholder mengetahui apa-apa yang sangat diperlukan adalah bagaimana menghubungkan pekerjaan yang mereka lakukan dengan ketersediaan modal agar memungkinkan kelompok ini meningkatkan kemampuan ekonomi mereka, dan memperoleh sumber pendapatan. (Bidang Pengkajian Sumberdaya UKMK Kementrian Negara Koperasi dan UKM, 2007)

Dalam hal ini peran Lembaga Keuangan Mikro Syariah Baitul Maal wat Tamwil (BMT) sangat cocok untuk menanggulangi masalah ini. Lembaga Keuangan Mikro Syariah Baitul Maal wat Tamwil (BMT) adalah lembaga yang fokus dalam menangani pembiayaan sektor usaha mikro.

BMT merupakan bentuk Lembaga Jasa Keuangan Mikro Syariah yang keberadaannya sangat dibutuhkan oleh masyarakat. Terutama masyarakat di bidang usaha mikro bahkan di bawah itu. Menurut definisi pemerintah usaha mikro memiliki kekayaan bersih sebesar Rp 50 juta tidak termasuk tanah dan bangunan. Sedangkan masyarakat yang datang ke BMT rata-rata adalah para usaha yang memiliki kekayaan jauh di bawah angka tersebut, seperti tukang sayur di pasar tradisional, pedagang bakso keliling, pedagang sayur dan lainlain. Dan menurut data UMKM yang di keluarkan oleh kemenkop tahun 2011 jumlah pelaku usaha mikro sebesar 54.559.969 dari total pelaku UMKM 55.206.444. Artinya usaha mikro sangat mendominasi sebesar 99\% dari pelaku UMKM.

Sebenarnya permasalahan yang timbul pada penelitian ini tidak hanya pada sisi Usaha Mikro yang tidak memiliki laporan keuangan yang memadai, tetapi timbul juga permasalahan pada sisi BMT dalam menganalisis aspek keuangan nasabah pembiayaan. Saat ini, yang dilakukan BMT ketika nasabah mengajukan pembiayaan untuk modal usaha, seorang analis pembiayaan mewawancarai sekaligus membuat laporan keuangan sederhana berupa arus kas. Padahal, dalam menilai aspek keuangan nasabah pembiayaan tidak cukup hanya arus kas saja. Harus dilakukan secara komprehensif dari sisi neraca, laba rugi, arus kas. Selain itu juga analis pembiayaan harus menerapkan penilaian kinerja manajemen usaha yang dijalaninya dari mulai aspek legalitas usaha, produksi, penjualan dan pemasaran.

Dalam penelitian ini penulis menggunakan teori analisis pembiayaan usaha mikro sebagai alat untuk menilai aspek usaha dari nasabah pembiayaan 
salah satunya aspek keuangan. Metodologi yang digunakan deskiptif kualitatif yaitu menggambarkan sebuah fenomena yang terjadi untuk dicari model atau rancangan yang tepat dari permasalahan yang terjadi.

Dari permasalahan tersebut perlu adanya sebuah inovasi baru yang dikeluarkan oleh BMT terkait rancangan form aplikasi pembiayaan yang terhubung langsung ke format laporan keuangan usaha mikro yang menjadi nasabah pembiayaan di BMT.

\section{LANDASANTEORI}

\subsection{BAITUL MAAL WAT TAMWIL}

Kegiatan BMT meliputi (Ridwan, 2006) :

a. Penghimpunan Dana

Modal awal BMT diperoleh dari simpoksus para pendiri dan seterusnya berasal dari DPK, missal Simpok, Simwa, Simpoksus. Modal dapat juga diperoleh dari kerjasama dengan berbagai pihak seperti Bank/lembaga lain seperti BUMN, departemen, LSM dan organisasi lainnya yang akan memperoleh bagi hasil dari BMT.

b. Pembiayaan.

Pemberian pembiayaan kepada anggota dan non anggota dilihat dari penilaian kelayakan suatu usaha berdasarkan prosedur masing-masing BMT. Prinsip ini akan mendapat bagi hasil. Adapun jenis akad dalam pembiayaan adalah mudharabah, murabahah, ijarah, musyarakah.

c. Jasa

Jasa dalam hal ini adalah pemberian mandate yang pada umumnya dituangkan dalam perjanjian jasa yang diperoleh dimasukkan sebagai pendapatan BMT.

d. Sosial.

Kegiatan sosial ini berasal dari Zakat, Infak, Sodakoh (ZIS), kegiatan ini tidak mengambil keuntungan financial, tetapi hanya pinjaman kebajikan. Contohnya dalam bentuk hibah atau Qardhul hasan.

Dari uraian diatas dapat disimpulkan peran BMT tergolong menjadi tiga yaitu penghimpunan dana malalui tabungan, penyaluran dana berupa pembiayaan dan jasa lainnya.

\subsection{USAHA MIKRO, KECIL, DAN MENENGAH (UMKM)}

Definisi UMKM Menurut Undang-Undang No. 20 Tahun 2008 tentang Usaha Mikro, Kecil, dan Menengah (UMKM) sama dengan yang didefinisikan oleh Kementerian Koperasi dan UKM, yaitu Usaha Mikro adalah usaha produktif milik orang perorangan dan/atau badan usaha perorangan yang memenuhi kriteria Usaha Mikro sebagaimana diatur dalam Undang-Undang ini. Usaha Kecil adalah usaha ekonomi produktif yang berdiri sendiri, yang dilakukan oleh orang perorangan atau badan usaha yang bukan merupakan anak perusahaan atau bukan cabang perusahaan yang dimiliki, dikuasai, atau menjadi bagian 
baik langsung maupun tidak langsung dari Usaha Menengah atau Usaha Besar yang memenuhi kriteria Usaha Kecil sebagaimana dimaksud dalam UndangUndang ini. Usaha Menengah adalah usaha ekonomi produktif yang berdiri sendiri, yang dilakukan oleh orang perorangan atau badan usaha yang bukan merupakan anak perusahaan atau cabang perusahaan yang dimiliki, dikuasai, atau menjadi bagian baik langsung maupun tidak langsung dengan Usaha Kecil atau Usaha Besar dengan jumlah kekayaan bersih atau hasil penjualan tahunan sebagaimana diatur dalam Undang-Undang ini.

\subsection{LAPORAN KEUANGAN}

Laporan keuangan yang dibuat oleh perusahaan terdiri dari beberapa jenis, tergantung dari maksud dan tujuan pembuatan laporan keuangan tersebut. Masing-masing laporan keuangan memiliki arti sendiri dalam melihat kondisi keuangan perusahaan, baik secara bagian maupun secara keseluruhan. Namun, dalam praktiknya perusahaan dituntut untuk menyusun beberapa jenis laporan keuangan yang sesuai dengan standar yang berlaku, terutama untuk kepentingan diri sendiri maupun untuk kepentingan pihak lain. "Dalam praktiknya secara umum ada lima jenis laporan keuangan (SAK ETAP 2009) diantaranya : 1) Neraca, 2) Laporan Laba Rugi, 3) Laporan Perubahan Ekuitas, 4) Laporan Arus Kas, 5) Catatan Atas Laporan Keuangan,”.

Neraca merupakan komponen laporan keuangan yang menunjukkan posisi keuangan perusahaan pada tanggal, bulan dan tahun tertentu. Arti dari posisi keuangan yang dimaksud adalah menggambarkan posisi jumlah dan jenis aktiva (harta) dan pasiva (kewajiban dan ekuitas) suatu perusahaan.

Laporan laba rugi merupakan laporan keuangan yang menggambarkan hasil usaha perusahaan dalam suatu periode tertentu. Dalam laporan laba rugi tergambar jumlah pendapatan dan sumber-sumber pendapatan yang diperoleh kemudian tergambar pula beban-beban yang dikeluarkan pada periode tertentu. Dari jumlah pendapatan dan beban tersebut terdapat selisih laba atau rugi. Jika jumlah pendapatan lebih besar dari beban perusahaan dikatakan laba, dan sebaliknya jika pendapatan lebih kecil dari beban perusahaan dikatakan rugi.

Laporan arus kas merupakan laporan yang menunjukkan semua aspek yang berkait dengan kegiatan perusahaan, baik yang berasal dari aspek operasi, aspek investasi dan aspek pendanaan perusahaan. Laporan arus kas harus disusun berdasarkan konsep kas selama periode tertentu. Laporan kas terdiri arus kas masuk dan arus kas keluar selama periode tertentu.

2.4 PEMBIAYAAN LEMBAGA KEUANGAN SYARIAH

\section{Definisi Pembiayaan}

Pembiayaan berarti financing atau pembelanjaan yaitu pendanaan yang dikeluarkan untuk mendukung investasi yang telah direncanakan, baik dilakukan sendiri maupun dijalankan oleh orang lain. (Muhammad, 2005) Adapun menurut Undang-Undang No. 21 Tahun 2008 tentang Perbankan Syariah, pembiayaan adalah penyediaan dana atau tagihan yang dipersamakan dengan itu berupa 
transaksi bagi hasil, transaksi sewa menyewa, transaksi jual beli, transaksi pinjam meminjam, dan multijasa

\section{Kelayakan Pembiayaan}

Baitul Maal wat Tamwil (BMT) harus mempunyai keyakinan atas kemauan dan kemampuan calon nasabah penerima fasilitas untuk melunasi seluruh kewajiban pada waktunya, sebelum BMT menyalurkan dana kepada nasabah, oleh karenanya penting untuk melakukan penilaian kelayakan pembiayaan. "Analisa kelayakan pembiayaan yaitu teknik analisis yang dilakukan secara cermat dan teliti dengan senantiasa memerhatikan atau berpedoman pada ketentuan yang berlaku, mencakup analisis kualitatif dan analisis kuantitatif,". (Veithzal, 2008).

Analisa kelayakan pembiayaan diperlukan dalam rangka untuk menilai potensi calon nasabah dalam pengajuan pembiayaan.

\section{Aspek-aspek Analisa dalam Kelayakan Pembiayaan}

Dalam penilaian aspek kelayakan pembiayaan terdiri dari aspek pemasaran, keuangan, manajemen, teknis, jaminan dan analisis dampak lingkungan. Yang perlu diperhatikan dalam aspek pemasaran adalah kemampuan perusahaan memasarkan barang produksi/jasa, hasil usahanya baik yang sekarang maupun yang direncanakan.

Evaluasi kondisi keuangan calon debitur dapat dilakukan dengan melihat laporan keuangan berupa neraca dan laba rugi perusahaan, analisis rasio keuangan, dan proyeksi arus kas calon debitur (Veithzal, 2008). Dalam penelitian ini, akan digunakan analisis rasio profit margin. Profit Margin merupakan kemampuan perusahaan untuk menghasilkan keuntungan dibandingkan dengan penjualan yang dicapai (Sutrisno, 2003).

Dalam aspek manajemen hal yang perlu diperhatikan adalah latar belakang pendidikan dan keahlian; kemampuan mengelola administrasi, keuangan dan faktor produksi seperti tenaga kerja; riwayat usaha, maupun riwayat hubungannya dengan bank; serta regenerasi pengelola usaha

Ketepatan memilih sarana produksi akan berpengaruh pada kualitas dan biaya produksi barang yang dihasilkan. Pemilihan secara tepat sarana tersebut akan menghasilkan barang dengan kualitas baik dan biaya produksi rendah dan sebaliknya. (Veithzal, 2008). Secara umum penilaian aspek teknis harus mencakup lokasi usaha, tenaga kerja, dan sarana prasarana.

\section{METODOLOGIPENELITIAN}

\subsection{PENDEKATAN DAN JENIS PENELITIAN}

Dalam penelitian ini digunakan pendekatan kualitatif. Pendekatan kualitatif adalah penelitian yang berlandaskan pada filsafat positivisme, digunakan untuk meneliti pada kondisi obyek yang alamiah, dalam hal ini peneliti adalah sebagai instrumen kunci, pengambilan sampel sumber data dilakukan secara purposive dan snowball, teknik pengumpulan dengan trianggulasi (gabungan), analisis 
data bersifat induktif/kualitatif, dan hasil penelitian kualitatif lebih menekankan makna dari pada generalisasi. (Sugiyono, 2009)

Penggunaan pendekatan penelitian kualitatif karena peneliti bermaksud memahami situasi sosial secara mendalam, menemukan pola, hipotesis dan teori. (Sugiyono, 2009)

Jenis penelitian yang digunakan adalah penelitian deskriptif. Penelitian deskriptif adalah penelitian yang dilakukan untuk mengetahui nilai variabel mandiri, baik satu variabel atau lebih (independen) tanpa membuat perbandingan atau menghubungkan dengan variabel lain (Sugiyono, 2009)

Dalam penelitian ini, peneliti meneliti tentang rancangan form aplikasi pembiayaan dan format laporan keuangan usaha mikro. Variabel mandiri dalam penelitian ini yaitu form aplikasi pembiayaan yang terhubung langsung ke format laporan keuangan usaha mikro yang nantinya akan digunakan oleh BMT untuk mempermudah dalam menilai aspek keuangan nasabah pembiayaan. Untuk memudahkan dalam pembahasan tersebut, peneliti melakukan survei lapangan terkait sistem keuangan Usaha Mikro yang menjadi nasabah BMT, selanjutnya peneliti melakukan survei lapangan untuk melihat cara BMT dalam menganalisis kinerja keuangan Usaha Mikro dengan mengumpulkan data-data primer, observasi, dan wawancara langsung ke Usaha Mikro dan BMT dan selanjutnya peneliti membuat rancangan form aplikasi pembiayaan dan format laporan keuangan usaha mikro.

\subsection{SITUASI SOSIAL DAN SAMPEL PENELITIAN}

\section{Situasi Sosial}

Dalam pendekatan kualitatif tidak menggunakan istilah populasi tetapi oleh Spradley dinamakan "social situation", dimana situasi sosial tersebut dapat dinyatakan sebagai obyek penelitian yang ingin lebih dipahami secara mendalam "apa yang terjadi" didalamnya. Pada situasi sosial atau obyek penelitian ini peneliti dapat mengamati secara mendalam aktivitas (activity) orang-orang (actors) yang ada pada tempat (place) tertentu. (Sugiyono, 2009). Situasi sosial dalam penelitian ini adalah BMT dalam menganalisis aspek keuangan Usaha Mikro tidak secara komprehensif hanya menilai aspek arus kas saja, dan BMT kesulitan mendapatkan data laporan keuangan nasabah pembiayaan dikarenakan Usaha Mikro yang menjadi nasabah pembiayaan BMT tidak memiliki laporan keuangan yang memadai.

\section{Sampel}

Teknik pengambilan sampel yang digunakan adalah Purposive Sampling, yaitu pemilihan sampel berdasarkan pada karakteristik tertentu yang dianggap mempunyai sangkut paut dengan karakteristik populasi yang sudah diketahui sebelumnya (Ruslan, 2006). Dalam penelitian ini, sampel yang diteliti berdasarkan teknik purposive sampling tersebut adalah pelaku Usaha Mikro yang tidak memiliki laporan keuangan memadai dan Praktisi BMT yang melakukan analisis pembiayaan. Dalam hal ini peneliti mengambil beberapa sample nasabah pembiayaan di BMT. BMT Nusantara, BMT Solusi H, dan BMT At-Tawfin. 


\section{Sumber Data dan Teknik Pengumpulan Data}

Dalam penelitian ini menggunakan data primer. Pengambilan data primer melalui observasi, wawancara objek penelitian dan dokumentasi.

a. Observasi

Observasi dilakukan melalui pengamatan pada kegiatan operasional yang dilakukan BMT dalam menganalisis nasabah pembiayaan dari semua aspek. Dari kegiatan survey, wawancara, hingga proses analisis dan proses collecting ke nasabah pembiayaan yang ada di pasar-pasar. Observasi juga dilakukan ke Usaha Mikro yang menjadi nasabah pembiayan BMT guna mengetahui operasional usaha yang diajalaninya.

b. Wawancara

Peneliti mewawancarai analis pembiayaan di BMT guna mendapatkan informasi cara analis pembiayaan di BMT dalam menilai aspek keuangan nasabah pembiayaan. Dan mewawancarai Usaha Mikro mengenai proses bisnis yang dijalaninya. Wawancara dilakukan dengan analis pembiayaan di BMT dan pelaku Usaha Mikro yang tidak memiliki laporan keuangan memadai. Pertanyaan wawancara bersifat terbuka dan secara garis besar adalah sebagai berikut:

Bagaimana cara analis pembiayaan di BMT dalam menilai aspek keuangan nasabah pembiayaan yang tidak memiliki laporan keuangan yang memadai ?

Bagaimana cara pelaku Usaha Mikro yang tidak memiliki laporan keuangan untuk mengetahui laba usahanya?

c. Dokumentasi

Dalam penelitian ini dokumentasi yang dikumpulkan yaitu berupa dokumen tertulis atau berkas nasabah pembiayaan di BMT, yaitu formulir aplikasi pembiayaan, memorandum akad pembiayaan, dan form analisa kemampuan bayar anggota pembiayaan. Selain itu dokumen berupa foto-foto yaitu dokumentasi gambar kondisi Usaha Mikro di pasar.

4. Teknik dan Proses Analisis Data

a. Analisis pendahuluan \& perancangan

Membuat rancangan form aplikasi pembiayaan dan format laporan keuangan usaha mikro berdasarkan analisis data sekunder yaitu dari sebuah teori manajemen pembiayaan lembaga keuangan syariah, dan SAK ETAP.

b. Analisis data di lapangan

Membuat analisis data dari hasil observasi dan wawancara, serta dokumentasi yang diperoleh. Untuk teknik wawancara, apabila jawaban hasil wawancara belum memadai sebagai bahan analisis, maka dilanjutkan dengan pertanyaan yang lebih mendalam, sampai tahap tertentu, diperoleh data yang kredibel.

c. Pengujian rancangan

Melakukan pengujian rancangan form aplikasi pembiayaan dan format laporan keuangan usaha mikro yang menjadi nasabah pembiayaan dalam rangka menganalisis kesiapan rancangan untuk digunakan dalam praktik di BMT. 


\section{PEMBAHASAN}

\subsection{PENERAPAN AKUNTANSI PADA USAHA MIKRO}

Penerapan akuntansi Usaha Mikro masih sebatas pada penerapan akuntansi pada umumnya. Yaitu penerimaan usaha dari siklus usahanya dan beban-beban yang terjadi selama usahanya berjalan. Kesalahan yang terjadi dalam pencatatan Usaha Mikro adalah total pendapatan usahanya digabung dengan total pendapatan lainnya diluar usaha. Adapun beban-beban yang terjadi ketika usahanya berjalan digabung juga dengan beban-beban kehidupan sehari-hari. Oleh karena itu perlu adanya pemisahan pendapatan usaha dengan pendapatan diluar usaha seperti gaji, dan perlu adanya pemisahan beban usaha dengan beban kebutuhan pribadi. Beban kebutuhan pribadi bukan termasuk beban usaha tetapi akan masuk di arus kas entitas usaha mikro sebagai pengurang dari aktivitas pendanaan sama halnya dengan prive.

\subsubsection{Perhitungan Pendapatan UMKM}

1. Pendapatan usaha

Pendapatan usaha adalah pendapatan yang diperoleh dari siklus usaha yang dijalaninya bisa berupa hasil penjualan barang atau jasa. Tergantung dari jenis usahanya

2. Pendapatan lain-lain

Pendapatan lain-lain dalam Usaha Mikro adalah pendapatan yang diperoleh diluar usahanya. contohnya adalah pendapatan gaji suami/istri dari instansi lain.

Dalam penghitungan pendapatan usaha dan pendapatan lain-lain tersebut kemudian diklasifikasikan lagi dengan lebih terperinci, sehingga dapat diperoleh angka atau pendapatan yang diterima setiap periode pelaporan akuntansi.

\subsubsection{Perhitungan beban Usaha Mikro}

Beban usaha adalah beban yang dikeluarkan untuk membiayai proses pencapaian hasil usaha. Dalam perhitungan beban Usaha Mikro, beban usaha tersebut kemudian diklasifikasikan lagi dengan terperinci. Sehingga dapat diperoleh angka atau beban yang harus dikeluarkan setiap periode akuntansi. 1. Beban usaha, terdiri dari :
a. Pembelian barang/HPP
b. Beban transportasi / ongkos
c. Beban tenaga kerja
d. Beban keamanan / kebersihan
e. Beban listrik / air / telpon
f. Beban perawatan inventaris
g. Beban promosi
h. Beban lain-lain 


\subsubsection{Perhitungan Beban "Biaya Hidup Usaha Mikro"}

Dalam pencatatan akuntansi Usaha Mikro tidak dapat dihindari dari karakteristik usaha mikro yaitu masih menggabungkan uang pribadi dengan uang usaha, oleh karena itu perlu adanya pemisahan antara keuangan usaha dengan keuangan pribadi agar metode akuntansinya sesuai dengan standar yang berlaku.

Biaya hidup usaha mikro biasanya diambil dari keuangan usahanya untuk memenuhi kebutuhan hidupnya. Dalam metode perhitungannya biaya hidup masuk kategori prive. Dalam perhitungan biaya hidup usaha mikro tersebut kemudian diklasifikasikan lagi dengan terperinci. Sehingga dapat diperoleh angka yang harus dikeluarkan setiap periode akuntansi.

1. Daftar biaya hidup (kategori Prive)

a. Beban konsumsi dan transportasi

b. Beban listrik / air / telpon dirumah

c. Beban SPP pendidikan

d. Buku pelajaran sekolah

e. Periksa kesehatan

f. Arisan

g. Rekreasi

h. Kiriman untuk orang tua

i. Beban cicilan rumah

j. Beban cicilan kendaraan

k. Beban rokskma usaha

1. Beban iuran desaa

Kas dan setara kas Yang menjadi cirihas dari laporan keuangan usaha mikro adalah adanya

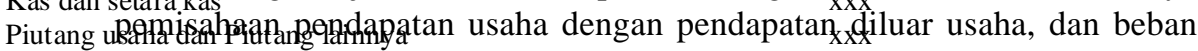
Persediaatusaha dengan beban untuk kepentingan pribadi Properti investasi

Aset tetap 4.1.4 Format Laporan Keuangan Usaha Mikro TOTAL ASET

$\mathrm{XXX}$

$\mathrm{XXX}$

L Laporan keuangan usaha mikro yang menjadi nasabah pembiayaan BMT

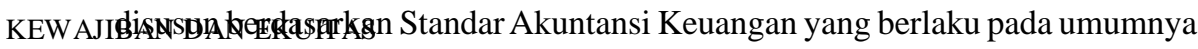
KEW AJIBatNberdasarkan kebutuhan dilapangan.

Utang usaha

Utang Bank

Ekuitas

$\mathrm{XXX}$

TOT AL

\section{$\mathrm{XXX}$}

$\mathrm{XxX}$

XXX 


$\begin{array}{lc} & \begin{array}{c}\text { Nama usaha } \\ \text { Laporan Laba Rugi } \\ \text { Per 31 Desember 20xx }\end{array} \\ & \\ \begin{array}{l}\text { Pendapatan usaha dan pendapatan lainnya } \\ \text { Pendapatan usaha }\end{array} & \\ \text { Pendapatan lainn ya } & \mathrm{xxx} \\ \text { Total Pendapatan } & \mathrm{xxx} \\ \text { Beban pokok penjualan } & \mathrm{xxx} \\ \text { Laba Bruto } & (\mathrm{xxx}) \\ \text { Beban Operasi } & \mathrm{xxx} \\ \text { Beban tenaga kerja } & \\ \text { Beban listrik, air \& telpone } & \mathrm{xxx} \\ \text { Beban kebersihan dan keamanan } & \mathrm{xxx} \\ \text { Beban transportasi } & \mathrm{xxx} \\ \text { Beban pemasaran } & \mathrm{xxx} \\ \text { Beban operasi lain } & \mathrm{xxx} \\ \text { Total Beban Operasi } & \mathrm{xxx} \\ \text { Laba Bersih } & \mathrm{xxx} \\ & \mathrm{xxx}\end{array}$

Nama Usaha
Laporan Arus Kas
Per 31 Desember 20xx

Aktivitas Operasi

Kas Masuk

Penerimaan

$\mathrm{xxx}$

Kas Keluar

Beban operasi

Arus kas bersih dari aktivitas operasi

$(\mathrm{xxx})$

$\mathrm{xxx}$

Aktivitas Investasi

Kas Masuk

Penjualan Aset $\quad$ Xxx

Kas Keluar

Pembelian Aset

Arus kas bersih dari aktivitas investasi

$(\mathrm{xxx})$

Aktivitas Pendanaan

Kas Masuk

Penambahan modal

$\mathrm{xxx}$

Kas keluar

Pembayaran hutang $\quad$ (xxx)

Prive (xxx)

Arus kas bersih dari aktivitas pendanaan $\quad \mathrm{xxx}$

Total Arus Kas

Saldo Awal Kas

Total Arus Kas Seharusnya 
Laporan keuangan usaha mikro pada umumnya sama dengan laporan keuangan pada umumnya, sifatnya lebih sederhana.

\section{A. RANCANGAN FORM APLIKASI PEMBIAYAAN}

Rancangan form aplikasi pembiayaan di BMT terdiri dari data pribadi calon mitra binaan yang menggambarkan identitas diri dari calon mita binaan, data permohonan menggambarkan tujuan dari pengajuan pembiayaan dan jumlah plafond pembiayaan yang diajukan, data usaha/objek menggambarkan jenis usaha dan tempat usaha, alasan pemilihan usaha menggambarkan analisis SWOT dari usahanya, aspek lingkungan menggambarkan kondisi lingkungan tempat usaha seperti kemudahan akses transportasi dan kondisi usaha yang sejenis, aspek pemasaran menggambarkan cara calon mitra binaan dalam memasarkan produknya dan nilai rupiah yang dikeluarkan untuk promosi, aspek operasional menggambarkan cara calon mitra binaan dalam mendapatkan bahan baku atau barang yang dijual sehingga terlihat harga pokok penjualan dari barang yang dijualnya, aspek SDM menggambarkan kuantitas tenaga kerja dan jumlah beban gaji yang dikeluarkan.

Dari beberapa aspek analisis diatas akan menghasilkan output laporan keuangan neraca, laba rugi dan arus kas calon mitra binaan yang nantinya menjadi sebuah rancangan format laporan keuangan usaha mikro.

Tabel 1. Form Aplikasi Data Pribadi Calon Mitra Binaan

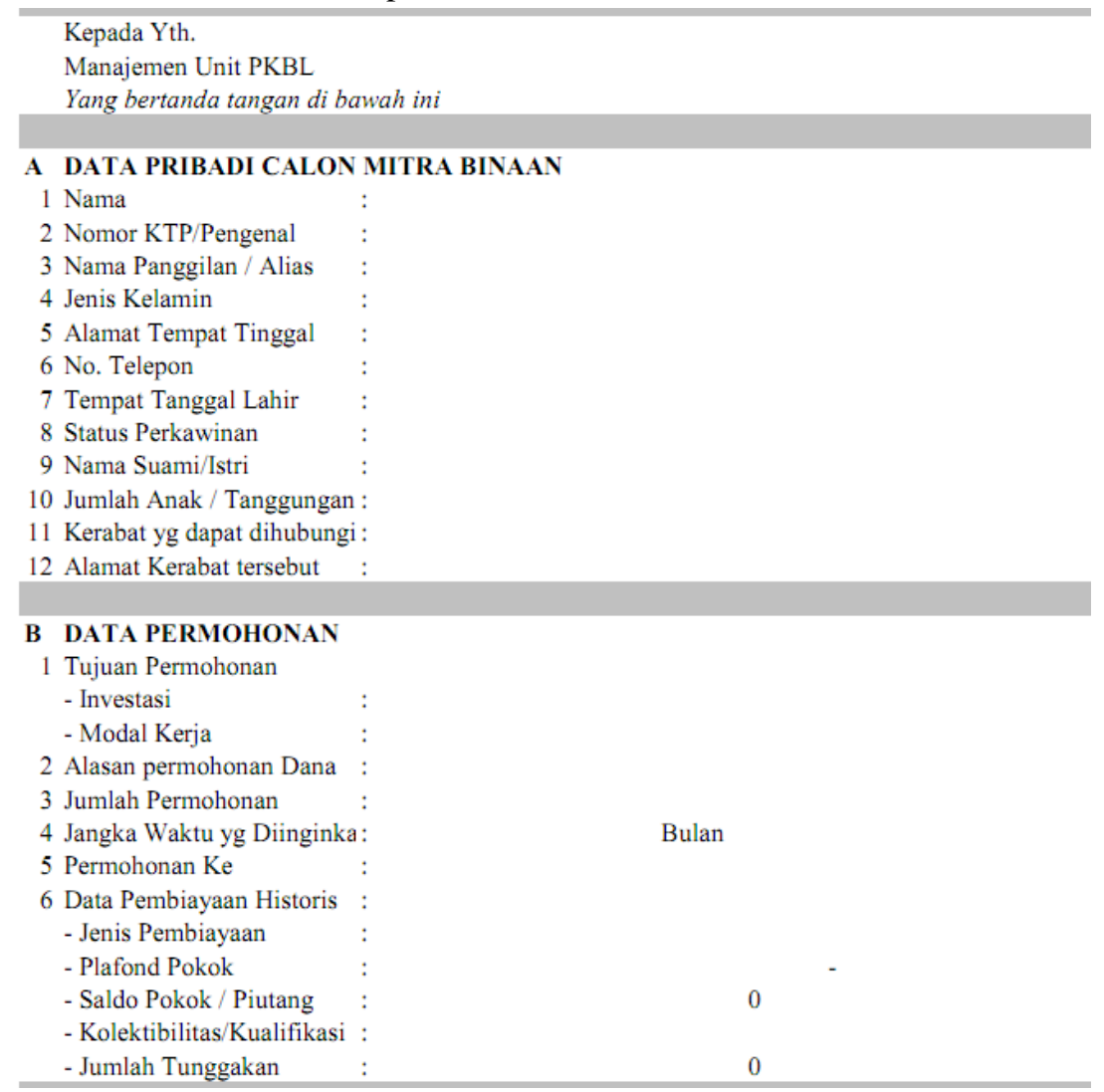




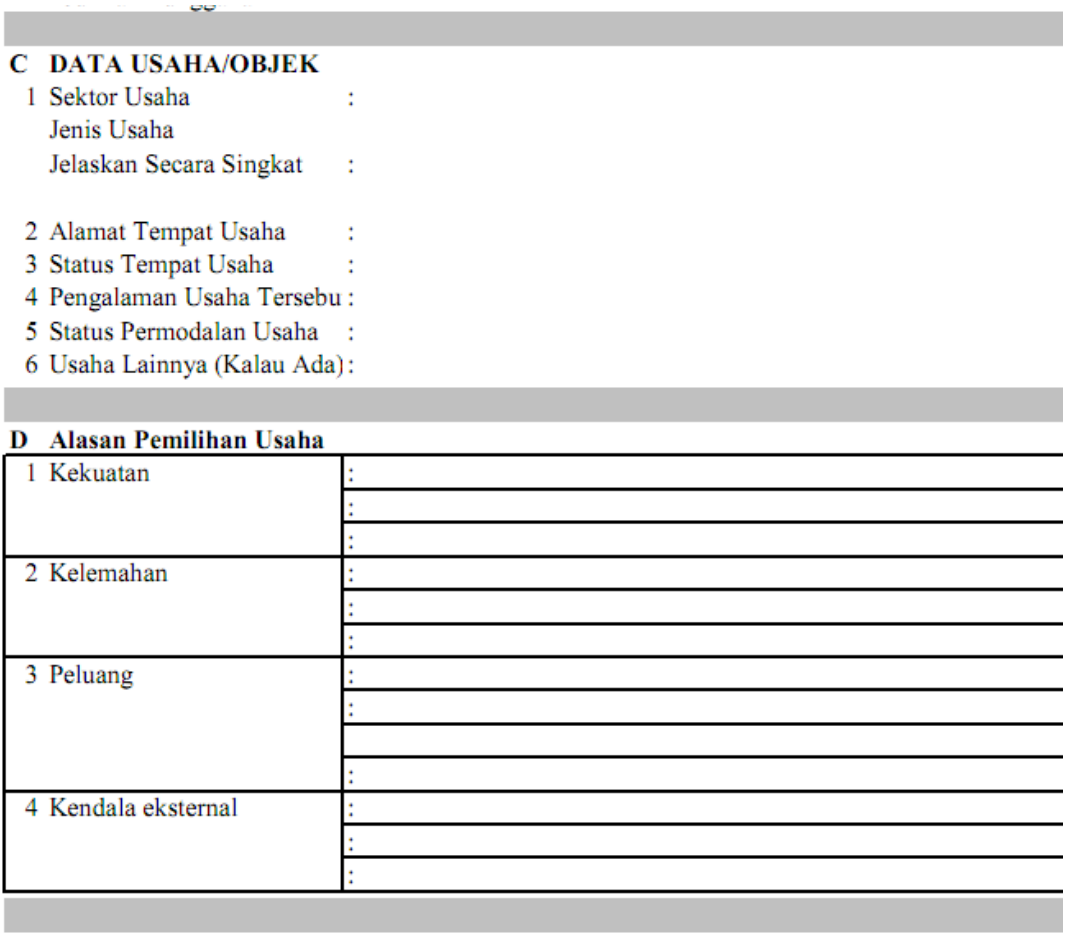

Input data yang harus di masukan dalam Formulir aplikasi ini dengan lengkap yang terdiri dari :

1. Data Pribadi calon nasabah

Berisikan identitas dari pemohon

2. Data permohonan

Berisikan data permohonan yang diajukan berapa, kemudian permohonan ke berapa, bagaimana data historis pembiayaan sebelumnya

3. Data Usaha

Menjelaskan usaha yang dijalankan oleh si pemohon

4. Alasan pemilihan usaha

Mengukur kapasitas yang di miliki oleh si pemohon dalam mengelola usahanya, sekaligus menggali potensi-potensi apa yang dapat di garap oleh usaha tersebut

5. Analisa aspek lingkungan

Melihat bagaimana kondisi dari lingkungan usaha yang dijalankan mulai dari persaingan dan potensi pasar di wilayah sekitar. Kemudian jika ada jasa keamanan di wilayah tersebut berapa biaya yang harus di keluarkan 
Tabel 2. Form Aplikasi Aspek Pemasaran

Distribusi

\begin{tabular}{|r|l|l|l|l|l|}
\hline No & Nama Produk & Agen & Sub-Agen & Pengecer & Konsumen \\
\hline \hline 1 & & & & & \\
\hline 2 & $\ldots \ldots \ldots \ldots \ldots$. & & & & \\
\hline 3 & $\ldots \ldots \ldots \ldots \ldots \ldots . . \ldots \ldots \ldots \ldots$ & & & & \\
\hline 4 & $\ldots \ldots \ldots \ldots \ldots \ldots$. & & & & \\
\hline
\end{tabular}

Promosi : 1. Direct; 2. Brosur; 3. Pameran; 4. Iklan

\begin{tabular}{|c|c|c|c|c|c|}
\hline No & Nama Produk & Promosi & Lainnya & Nilai Promosi & Rutinitas \\
\hline 1 & & & & $\begin{array}{ll}\mathrm{Rp} & - \\
\end{array}$ & \\
\hline 2 & 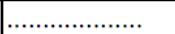 & & & $\mathrm{Rp}$ & \\
\hline 3 & …………..... & & & $\mathrm{Rp}$ & \\
\hline 4 & …………...... & & & $\mathrm{Rp}$ & \\
\hline
\end{tabular}

\section{Harga Jua}

\begin{tabular}{|r|l|l|lc|}
\hline No & Nama Produk & Satuan & \multicolumn{2}{|c|}{ Harga } \\
\hline \hline 1 & & & & \\
\hline 2 & $\ldots \ldots \ldots \ldots \ldots \ldots$ & & $\mathrm{Rp}$ & - \\
\hline 3 & $\ldots \ldots \ldots \ldots \ldots \ldots$ & & $\mathrm{Rp}$ & - \\
\hline 4 & $\ldots \ldots \ldots \ldots \ldots \ldots$ & & $\mathrm{Rp}$ & - \\
\hline
\end{tabular}

\section{Tempat}

\begin{tabular}{|r|l|l|l|l|ll|}
\hline No & Jenis Tempat & Kuantitas & Luas Bangunan & Luas Tanah & Nilai Harga \\
\hline \hline 1 & & & & & $\mathrm{Rp}$ & - \\
\hline 2 & & & & & $\mathrm{Rp}$ & - \\
\hline 3 & & & & & $\mathrm{Rp}$ & - \\
\hline 4 & $\ldots \ldots \ldots \ldots \ldots$ & & \multicolumn{5}{|c|}{ Total } & $\mathrm{Rp}$ & - \\
\hline
\end{tabular}

B. Analisa Aspek Pemasaran

1. Mencakup bagaimana calon pemohon mendistribusikan hasil usahanya apakah melalui agen, sub-agen, pengecer atau langsung kepada konsumen.

2. Kemudian selanjutnya, bagaimana si calon nasabah melakukan promosi, apakah dengan cara direct atau dari mulut ke mulut, atau sudah menggunakan brosur sebagai media untuk mempromosikan usahanya. Analisa ingin melihat bagaimana calon nasabah memperkenalkan produknya dan bersaing dengan usaha lainnya yang sejenis. Input untuk nilai promosi berapa biaya yang di keluarkan dalam sebulan, apabila tidak ada isikan nilai " 0 "

3. Selanjutnya Input nilai harga jual dari produk usaha. Kemudian tempat yang digunakan sebagai tempat usaha apakah menggunakan gerobak, atau kontrak, atau memiliki bangunan sendiri. Apabila sewa input nilai sisa sewa tempat, apabila gerobak input nilai sisa dari penyusutan (Di taksir), apabila bangunan milik sendiri di taksir berapa nilai bangunannya, dan apabila satu dengan tempat tinggal tentukan apakah tempatnya lebih dominan untuk usaha atau tempat tinggal, apabila lebih dominan usaha tentukan nilainya untuk usaha. 
Tabel 3. Form Aplikasi Aspek Operasional

Sumber \& Cara Pembayaran Bahan Baku

\begin{tabular}{|r|c|l|l|l|l|l|}
\hline No & Bahan Baku & Satuan & Sumber & Pembayaran & Uang Muka & Pelunasan \\
\hline 1 & & & & & & \\
\hline 2 & & & & & & \\
\hline 3 & & & & & & \\
\hline 4 & & & & & & \\
\hline
\end{tabular}

Fasilitas Penunjang/Aktiva Tetap

\begin{tabular}{|c|c|c|c|c|c|c|c|c|}
\hline \multirow[t]{2}{*}{ No } & \multirow[t]{2}{*}{ Nama Barang } & \multirow[t]{2}{*}{$\begin{array}{c}\text { Jumlah } \\
\text { Unit }\end{array}$} & Harga & \multicolumn{2}{|c|}{ Jumlah } & \multirow[t]{2}{*}{$\begin{array}{c}\text { Umur } \\
\text { Ekonomis }\end{array}$} & \multicolumn{2}{|c|}{$\begin{array}{c}\text { Nilai } \\
\text { Penyusutan }\end{array}$} \\
\hline & & & & $\mathrm{Rp}$ & - & & $\mathrm{Rp}$ & - \\
\hline 2 & & & & Rp & - & & Rp & - \\
\hline 3 & & & $\mathrm{Rp}$ & $\mathrm{Rp}$ & - & & $\mathrm{Rp}$ & - \\
\hline 4 & & & $\mathrm{Rp}$ & Rp & - & & Rp & - \\
\hline
\end{tabular}

Desain Produk

\begin{tabular}{|r|l|l|ll|}
\hline \multicolumn{1}{|c|}{ No } & Produk & \multicolumn{2}{|l|}{ Design } & \multicolumn{2}{|c|}{ Nilai Design } \\
\hline 1 & & & $\mathrm{Rp}$ & - \\
\hline 2 & & & $\mathrm{Rp}$ & - \\
\hline 3 & & & $\mathrm{Rp}$ & - \\
\hline 4 & & & $\mathrm{Rp}$ & - \\
\hline
\end{tabular}

Proses Bisnis

\begin{tabular}{|c|c|c|c|c|c|}
\hline No. & Produk & Kuantitas & Satuan & Harga & HPP \\
\hline 1 & & & & & Rp - \\
\hline 2 & …................... & & & $\mathrm{Rp}$ & Rp \\
\hline
\end{tabular}

\begin{tabular}{|c|c|c|c|c|c|c|c|c|}
\hline \multirow{2}{*}{ No } & \multirow[t]{2}{*}{ Produk } & Harga & \multirow[t]{2}{*}{ Kuantitas Tunai } & \multicolumn{2}{|c|}{ Nilai Tunai } & \multirow[t]{2}{*}{\begin{tabular}{|l|}
$\begin{array}{l}\text { Kuantitas Di } \\
\text { tangguhkan }\end{array}$ \\
\end{tabular}} & \multicolumn{2}{|c|}{$\begin{array}{c}\text { Nilai } \\
\text { Piutang }\end{array}$} \\
\hline & & & & Rp & - & & Rp & - \\
\hline 2 & & $\mathrm{Rp}$ & & $\mathbf{R p}$ & - & & Rp & - \\
\hline 3 & & $\mathrm{Rp}$ & & $\mathrm{Rp}$ & - & & $\mathrm{Rp}$ & - \\
\hline 4 & & $\mathrm{Rp}$ & & $R p$ & - & & Rp & - \\
\hline 5 & & $\mathrm{Rp}$ & & $\mathrm{Rp}$ & - & & Rp & - \\
\hline
\end{tabular}

Biaya Umum

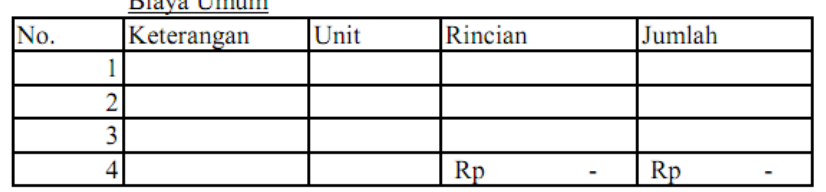

Pengawasan Kualitas

\begin{tabular}{|r|r|}
\hline Uraikan \\
\hline 1 & \\
\hline 3 & \\
\hline 4 & \\
\hline
\end{tabular}




\section{Analisa Aspek Operasional}

Input biaya yang dikeluarkan untuk design atau package dari produk usaha si calon nasabah. Inputan Proses bisnis di mulai dari HPP, yaitu berapa nilai pembeli persediaan barang yang akan di jual, apabila usaha yang dikelola calon nasabah melakukan proses produksi maka baris no. 2 dan seterusnya bisa di input dengan biaya produksi.

Kemudian sumber dan cara mendapatkan bahan baku, di input dari mana kemudian cara pembayaran apakah di lakukan dengan cara tunai atau di tangguhkan, apabila di tangguhkan di input sampai dengan berapa lama pada kolom Uang Muka

Data yang di input berikutnya adalah fasilitas penunjang atau aktiva tetap yang di miliki oleh si calon nasabah, apabila ada di taksir dulu nilai sisa dari Aktiva Tetap yang di miliki oleh si calon nasabah. Setelah itu tentukan umur eknomis kedapannya. Pendapatan penjualan tunai dan ditangguhkan. Input data ini sesuai dengan harga penjualan produk usaha si calon nasabah. Kemudian input kuantitas penjualan selama sebulan, data ini bisa di input dari rata-rata penjualan sebulan dengan mendapatkan data penjualan pada waktu sepi dan ramai, atau bisa di buat asumsi yang lainnya

Biaya Umum, data inputan mengenai biaya-biaya yang keluar akibat proses usaha yang terjadi, apabila usaha yang di jalankan masih tercampur antara keuangan usaha dan keluarga bisa di masukan biaya hidup. Pengawasan kualiatas, di input dan memasukan data kualitatif yang menguraikan bagaimana proses usaha atau produksi dilakukan, faktor-faktor apa saja yang sudah dillakukan sehingga dapat membuat produk usaha si calon nasabah itu berkualitas

Tabel 4. Form Aplikasi Aspek SDM

H Aspek SDM
\begin{tabular}{|r|l|l|l|l|ll|}
\hline No & Jabatan & Kuantitas & Pendidikan & Periode Kerja & Gaji & \\
\hline 1 & Karyawan & & & Bulan & $\mathrm{Rp}$ & - \\
\hline 2 & & & & & $\mathrm{Rp}$ & - \\
\hline 3 & & & & & $\mathrm{Rp}$ & - \\
\hline 4 & & & & & $\mathrm{Rp}$ & - \\
\hline
\end{tabular}

\section{Analisa Aspek SDM}

Input berapa karyawan yang ada dan berapa biaya SDM yang dikeluarkan untuk melakukan proses usaha.

Input dari aplikasi pembiayaan diatas akan menghasilkan output laporan keuangan neraca dan laba rugi nasabah pembiayaan, secara otomatis ada akun yang terkait dari data input dan ada juga akun yang tidak terkait. Misalnya kas dan penempatan kas di bank hal itu dapat ditanyakan langsung kepada calon mitra binaan BMT

Laporan keuangan neraca dan laba rugi berikut adalah hasil output data yang telah dimasukan diawal. perhatikan antara warna hitam bold dengan 
hitam, yang berwarna hita, bold tidak perlu di input secara manual ia tersambung otomatis dari inputan analisa yang sebelumnya, untuk berwarna hitam di input untuk menyesuaikan kembali dengan data-data yang ada dari si calon nasabah. Data tersebut seperti berapa kas yang ada untuk usaha, berapa modal awal ketika usaha pertama kali. Jika sulit buat asumsi untuk menyesuaikan laporan keuangan yang balance.

Tabel 5. Laporan Neraca dan Laba Rugi Calon Mitra Binaan

\begin{tabular}{|c|c|c|c|c|c|c|}
\hline AKTIVA & & & & PASIVA & & \\
\hline 1 Kas & : & $\mathrm{Rp}$. & 0 & 1 Kewajiban Usaha & $\mathrm{Rp}$. & 0 \\
\hline 2 Tab. Pada Bank/Koperasi & : & Rp. & 0 & 2 Investasi dari......... & Rp. & 0 \\
\hline 3 Piutang Dagang & : & Rp. & 0 & 3 Uang Muka Penjualan & Rp. & 0 \\
\hline 4 Persediaan Barang Dagang & : & $\mathrm{Rp}$. & 0 & 4 PPN Penjualan & Rp. & 0 \\
\hline 5 Inventaris Usaha & : & Rp. & 0 & 5 Kewajiban Lain-lain & Rp. & 0 \\
\hline 6 Bangunan/Tmp Ush/Grobak & : & Rp. & 0 & $6 \mathrm{ZIS}$ & Rp. & 0 \\
\hline 7 Aktiva Tetap & : & Rp. & 0 & 7 Modal & $\mathrm{Rp}$. & \\
\hline $8 \ldots \ldots \ldots \ldots . .$. & : & Rp. & 0 & 8 SHU & Rp. & 0 \\
\hline 9 Rek Selisih & : & Rp. & 0 & 9 .................... & Rp. & 0 \\
\hline Jumlah Aktiva & & Rp. & 0 & Jumlah Pasiva & Rp. & 0 \\
\hline Data Pendapatan Usaha & & & & Data Pengeluaran Usaha & & \\
\hline 1 Omset per Hari/Minggu/Bular & & Rp. & 0 & 1 Pembelian barang/HPP / bln & Rp. & 0 \\
\hline 2 Pendapatan Lainnya & : & Rp. & 0 & 2 Biaya usaha/ongkos per bln & Rp. & 0 \\
\hline 3 & : & Rp. & 0 & 3 Biaya tenaga kerja per bln & Rp. & \\
\hline 4 & : & Rp. & 0 & 4 Biaya keamanan/kebersihan & Rp. & 0 \\
\hline 5 & : & Rp. & 0 & 5 Biaya Listrik/telepon/air & Rp. & 0 \\
\hline 6 & : & Rp. & 0 & 6 Biaya perawatan inventaris & Rp. & 0 \\
\hline 7 & : & Rp. & 0 & 7 Biaya Promosi & Rp. & 0 \\
\hline 8 & & & & 8 Biaya lain-lain & Rp. & 0 \\
\hline & & isa $\mathrm{H}$ & $\mathrm{ir} / \mathrm{l}$ & & Rp. & \\
\hline
\end{tabular}

Dengan ini saya menyatakan bahwa data dan informasi tersebut di atas adalah benar, dengan melakukan proses wawancara kepada calon

Mitra Binaan

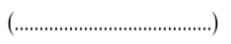

Jakarta, Januari 2013

Di buat oleh

Daftar biaya hidup dan daftar pendapatan lainnya adalah inputan yang akan terhubung dengan cash flow usaha. Inputan ini akan menghitung cash flow sampai dengan biaya hidup dan pendapatan lain di luar usaha yang akan menentukan kemampuan bayar dari nasabah.

Inputan ini sebagai pendekatan terhadap karakter para UMKM dan sebagai alat ukur dalam menentukan layak atau tidak layaknya pengajuan pembiayaan. Untuk pertanyaan Point no 1 s.d. 3 pilihan jawabnya hanya ya dan tidak. Input 4 jika "Tidak melakukan" input 1 jika "Melakukan". 


\section{E. Proyeksi Target Pembelian}

Inputan yang menyatakan rencana pembelian atas persediaan barang dagang atau pun bahan mentah, dengan standar harga yang di tentukan.

\section{F. Proyeksi Target Penjualan}

Inputan yang menyatakan rencana penjualan atas persediaan barang dagang atau pun barang siap jual, dengan standar harga yang di tentukan

Analisa diatas menggambarkan sebuah proses yang dilakukan oleh BMT dalam menganalisa aspek keuangan nasabah pembiayaan yang tidak memiliki laporan keuangan memadai. Dengan menggunakan rancangan format laporan keuangan usah mikro dan rancangan form aplikasi pembiayaan yang terhubung langsung ke format laporan keuangan.

Tabel 6. Form Aplikasi Daftar Biaya Hidup

\begin{tabular}{|c|c|c|c|c|c|}
\hline No. & Keterangan & Nilai & Quantity & Total & \\
\hline & Dapur & & & $\mathrm{Rp}$ & - \\
\hline$\overline{2}$ & Telepon & & & $\mathrm{Rp}$ & - \\
\hline 3 & Listrik & & & $\mathrm{Rp}$ & - \\
\hline 4 & Air & & & & \\
\hline 5 & Pendidikan & & & & \\
\hline & a. SPP Pendidikan & & & $\mathrm{Rp}$ & - \\
\hline & b. Uang Jajan + Transportasi & & & $\mathrm{Rp}$ & - \\
\hline & c. Buku Pelajaran & & & & \\
\hline & d. Lain-lain & & & & \\
\hline 6 & Kesehatan & & & & \\
\hline & a. Periksa kesehatan & & & & \\
\hline & b. Susu & & & & \\
\hline 7 & Arisan & & & $\mathrm{Rp}$ & - \\
\hline 8 & Rekreasi & & & & \\
\hline 9 & Kiriman ke Orang Tua & & & & \\
\hline 10 & Cicilan Rumah & & & & \\
\hline 11 & Cicilan Kendaraan & & & $\mathrm{Rp}$ & - \\
\hline 12 & Rokok & & & & \\
\hline 13 & Transportasi & & & $\mathrm{Rp}$ & - \\
\hline 14 & Iuran Desa & & & $\mathrm{Rp}$ & - \\
\hline 15 & Lain-lain tak terduga & & & $\mathrm{Rp}$ & - \\
\hline & \multicolumn{3}{|l|}{ Total Biaya Hidup } & $\mathrm{Rp}$ & - \\
\hline
\end{tabular}

Tabel 7. Form Pendekatan Karakter Mitra

\begin{tabular}{|c|l|c|l|l|l|}
\hline 1 & Tidak Berjudi \& Pemabuk & $\mathrm{V}$ & & & \\
\hline 2 & Tidak Emosional & $\mathrm{V}$ & & & \\
\hline 3 & Tidak Merokok & $\mathrm{V}$ & & & \\
\hline 4 & Amanah \& Taat Aturan & $\mathrm{V}$ & & & \\
\hline 5 & Komitmen Terhadap Hutang \& Janji & $\mathrm{V}$ & & & \\
\hline 6 & Sikap Bekerja Sama (Kooperatif) & $\mathrm{V}$ & & & \\
\hline 7 & Hubungan dg Orang Lain & $\mathrm{V}$ & & & \\
\hline
\end{tabular}


Tabel 1.8 Form Aplikasi Proveksi Pembelian dan Peniualan

\begin{tabular}{|c|c|c|c|c|c|c|c|c|c|c|c|c|c|c|c|c|c|}
\hline & & & & & & & & & & $\mathrm{RB}$ & & & & & & & \\
\hline & & & & & & & & & & & & & & & & & \\
\hline Kode Barang & Nama Barang & Satuan & Harga Beli & Asumsi & 1 & 2 & 3 & 4 & 5 & 6 & 7 & 8 & 9 & 10 & & & 12 \\
\hline & & & & & & & & & & & & & & & & & \\
\hline & & & & & & & & & & & & & & & & & \\
\hline & & & & & & & & & & & & & & & & & \\
\hline & & & & & & & & & & & & & & & & & \\
\hline & & & & & & & & & & & & & & & & & \\
\hline & & & & & & & & & & & & & & & & & \\
\hline & & & & & & & & & & & & & & & & & \\
\hline & & & & & & & & & & & & & & & & & \\
\hline & & & & & & & & & & & & & & & & & \\
\hline & & & & & & & & & & & & & & & & & \\
\hline & & & & & & & & & & & & & & & & & \\
\hline & & & & & & & & & & & & & & & & & \\
\hline & & & & & & & & & & & & & & & & & \\
\hline & & & & & & & & & & & & & & & & & \\
\hline
\end{tabular}

\begin{tabular}{|c|c|c|c|c|c|c|c|c|c|c|c|c|c|c|c|c|}
\hline \multirow[b]{2}{*}{ Kode Barang } & \multirow[b]{2}{*}{ Nama Barang } & \multirow[b]{2}{*}{ Satuan } & \multirow[b]{2}{*}{ Harga Jual } & \multirow[b]{2}{*}{ Asumsi } & \multicolumn{12}{|c|}{ BULAN } \\
\hline & & & & & 1 & 2 & 3 & 4 & 5 & 6 & 7 & 8 & 9 & 10 & 1 & 12 \\
\hline & & & & & & & & & & & & & & & & \\
\hline & & & & & & & & & & & & & & & & \\
\hline & & & & & & & & & & & & & & & & \\
\hline & & & & & & & & & & & & & & & & \\
\hline & & & & & & & & & & & & & & & & \\
\hline & & & & & & & & & & & & & & & & \\
\hline & & & & & & & & & & & & & & & & \\
\hline & & & & & & & & & & & & & & & & \\
\hline & & & & & & & & & & & & & & & & \\
\hline & & & & & & & & & & & & & & & & \\
\hline
\end{tabular}

5. KESIMPULAN

Usaha Mikro yang menjadi nasabah pembiayaan di BMT memiliki ciri khas tersendiri, sebagai usaha informal yang tidak memiliki manajerial yang baik. Salah satunya aspek manajerial keuangan. Usaha MIkro menggabungkan uang kebutuhan usaha dengan uang kebutuhan pribadi, selain itu pelaku Usaha Mikro tidak mengerti aspek pencatatan akuntansi. Sementara BMT memiliki keterbatasan dalam melakukan analisa aspek keuangan nasabah pembiayaan. Oleh karena itu diperlukan format laporan keuangan usaha mikro dan form aplikasi pembiayaan pada BMT. Dari penelitian ini diperoleh kesimpulan sebagai berikut:

Format laporan keuangan Usaha Mikro menjadi dasar dalam analisis aspek keuangan nasabah pembiayaan. Format laporan keuangan Usaha Mikro dibuat dalam rangka mengetahui posisi keuangan dan kinerja operasional dari Usaha Mikro tersebut. Agar terlihat aset dan kekayaan yang dimiliki oleh nasabah pembiayaan serta laba yang dihasilkan.

Form Aplikasi Pembiayaan, menjadi sebuah alat yang digunakan BMT dalam menganalisa aspek keuangan nasabah pembiayaan. Dari form ini dapat terlihat proses bisnis dari beberapa aspek seperti aspek lingkungan, aspek pemasaran, aspek operasional, aspek lingkungan. Semua aspek tersebut tidak terlepas dari kinerja keuangan usahanya. 
Dengan format laporan keuangan dan form aplikasi pembiayaan, analis pembiayaan di BMT akan dipermudah dalam menilai kinerja keuangan nasabah dan membina usaha mikro dalam hal manajerial keuangan.

\section{DAFTAR PUSTAKA}

Aziz, M. A. (2005). AD/ART BMT (Baitul Maal wat Tamwil. Jakarta: PINBUK.

Aziz, M. A. (2005). Tata Cara Pendirian BMT. Jakarta: PINBUK.

Badan Pusat Statistik . (n.d.). Retrieved from Badan Pusat Statistik: www.bps.go.id

Bank Indonesia: www.bi.go.id

Bank Indonesia. Undang-Undang No 21 Tahun 2008 Tentang Perbankan Syariah.

Buchori, N. S. (2012). Koperasi Syariah: Teori dan Praktik. Tangerang: Pustaka Aulia Media.

Budhiningsih, T. S. (2009). Kajian Kontribusi Kredit Bantuan Rakyat Dalam Mendukung Permodalan UMKM.

Departemen Pertanian. (2009). Identifikasi dan Kelayakan Usaha Mikro Agribisnis. Jakarta: Departemen Pertanian.

Deputi Bidang Pengkajian Sumberdaya UKMK Asdep Urusan Penelitian UKM. (2011). Kajian Dampak Kredit Usaha Rakyat .

Deputi Bidang Pengkajian Sumberdaya UKMK Kementrian Negara Koperasi dan UKM. (2007, Desember). Kredit Perbankan Bagi UMKM .

Deputi Pengkajian Sumberdaya UKMK Kementrian Negara Koperasi dan UKM. (2007). Kredit Perbankan Bagi UMKM. Jakarta: Infokop Media Pengkajian Koperasi Usaha Kecil dan Menengah.

Jusuf, J. (2006). Analisis Kredit Untuk Account Officer. Jakarta: PT Gramedia Pustaka Utama.

Kasmir. (2008). Analisis Laporan Keuangan. Jakarta: PT RajaGrafindo Persada.

Kasmir. (2002). Dasar-Dasar Perbankan. Jakarta: PT Raja Grafindo Pustaka Umum. 
Kementrian Koperasi dan UKM. (2008). Undang-Undang No. 20 . Jakarta.

Miller, L. V. (2002). People And Politicus and Cityzen Participation. Word Neight Bours.

Muhammad. (2005). Manajemen Pembiayaan Bank Syariah. Yogyakarta: Akademi Manajemen Perusahaan YKPN.

Muljono, P. T. (1993). Manajemen Perkreditan Bagi Bank Komersil. Yogyakarta: BPFE.

Nugroho, Y. Z. (2009). Ekonomi Kerakyatan: Usaha Mikro, Kecil, dan Menengah. Jakarta: Universitas Trisakti.

Siswoyo, M. M. (2010). Analisa Pembiayaan Retail. Jakarta: Bank Muamalat Indonesia.

Suhardjono. (2005). Manajemen Perkreditan Usaha Kecil dan Menengah. Yogyakarta: Akdemi Manajemen Perusahaan YKPN.

Sutojo, S. (1997). Analisa Kredit Bank Umum. Jakarta: Pustaka Binaman Pressindo.

Sutrisno, D. (2003). Manajemen Keuangan. Yogyakarta: Ekonesia FE UI.

Veithzal, V. R. (2008). Islamic Financial Management. Jakarta: Djambatan. 